\author{
Evangelos SISKOS, \\ Konstantia DARVIDOU
}

\title{
OIL AND NATURAL GAS TRADE BALANCE AND PRODUCTION EFFECTS IN THE EUROPEAN UNION AND BLACK SEA ECONOMIC COOPERATION COUNTRIES
}

\begin{abstract}
Most European Union and Black Sea Economic Cooperation countries are net importers of petroleum and natural gas. Searching for new deposits and construction of new pipelines can improve energy security in the region. The problem is topical for Greece which has a developed refinery industry and needs to improve its trade balance to repay the accumulated external and public debt. Several new pipeline initiatives through Greece can support relations between the EU and BSEC countries. The paper provides previous research review about energy dependency and the effects of trade, production and transportation of hydrocarbons. Next we provide analysis of the effect of the trade on balance of payments in both the EU and BSEC countries. Import dependency of GDP on oil and natural gas is especially large in Malta, Georgia, Ukraine, Serbia and Latvia. On the other hand Russia and Azerbaijan are large net exporters of hydrocarbons. Then we analyse the impact of mining on labour market and refinery indus-

(C) Evangelos Siskos, Konstantia Darvidou, 2017.

Siskos Evangelos, D. Sc. Econ., Professor of International Economic Relations, Western Macedonia University of Applied Sciences (Technological Educational Institute of Western Macedonia), Greece Darvidou Konstantia, Ph. D. of International Economic Relations Western Macedonia University of Applied Sciences (Technological Educational Institute of Western Macedonia), Greece.
\end{abstract}


try development. On average larger value added in mining leads to larger employment at least for males and middle age group of people. But the effect largely varies across countries and time periods. Together with construction of new pipelines growth of extraction can result in dozens of thousands of new jobs in Greece. There is a close link between value added in mining and compensation of employees in that industry. We have found evidence that the clustering effect between mining and manufacture of refined petroleum products and coke exists only in some EU countries.

\section{Key words:}

Oil and natural gas industry, trade balance, mining, energy supply, employment, European Union, Black Sea Economic Cooperation.

JEL: L71, L95, Q35, Q43, F14, J23.

\section{Introduction}

The European Union countries mainly depend on oil and natural gas imports. Searching for new deposits can improve their energy security. Especially this problem is topical for Greece under the need to improve its trade balance to repay the accumulated external and public debt. Despite natural gas intensity of Greek economy is not high, it largely depends on crude oil imports because of its developed and increasingly export-oriented refinery industry. Subject to better crude oil self-sufficiency and diversified export destinations (despite the expected 14\% decrease in European oil product demand in 2005-2030, the worldwide oil product demand is expected to grow by $23 \%$ (Lanz et al., (2012)) Greek refinery industry can be a driver for achieving trade surplus and secure macroeconomic stability.

Considering another group of countries (Black Sea Economic Cooperation member-state) is motivated by the fact that Greece is also its member. These countries include both net exporters and net-importers of oil and natural gas. But traditional net-importers try to search new deposits to substitute part of their energy imports. For example Costel (2011) assumes that the region can become an 
important oil and gas producing area considering potential for offshore extraction in such countries as Georgia, Ukraine, Bulgaria and Turkey.

Besides search for new deposits energy supply can be secured by construction of new pipelines. It can also support employment and GDP growth, although the effect for balance of payments will depend on ratio between transit and growth of domestic consumption of imported hydrocarbons. Several new pipeline initiatives can support links and relations between the EU and BSEC countries.

The paper is organized as follows. First we provide previous research review about energy dependency of European countries and Greece in particular and the effects of trade, production and transportation of hydrocarbons. Next we provide analysis of the effect of the trade on balance of payments in both the EU and BSEC countries. Then we analyse the impact of mining on labour market and refinery industry development mostly in the EU countries (considering the availability of comparable data).

\section{Previous research review}

Oil and gas import dependency. Christie E. (2007) measured oil and gas dependence vulnerability of EU-15 countries (see table 1 ). An import vulnerability indicator was a product of import dependency ratio (oil or gas imports from nonEEA countries to consumption ratio) and Herfindahl-Hirschman geographical concentration index of oil or gas imports). A $100 \%$ vulnerability means that a country imports $100 \%$ of the oil or gas that it consumes from a single exporting country. A combined vulnerability indicator is an import vulnerability indicator multiplied by petroleum products or natural gas intensity of GDP.

Finland, Belgium, Greece and Sweden were the most vulnerable by oil imports, while Finland, Austria, Italy and Germany by natural gas imports. Greece had the second worst gas import vulnerability indicator, but the combined vulnerability indicator was a median one because its natural gas intensity of GDP was low enough. The least vulnerable countries by oil and natural gas imports were Ireland, Denmark and United Kingdom.

Greece depends on imports of oil because of its refinery industry. Ausick P. (2015) noted that in 2012 crude oil accounted for $24 \%$ of Greece's imports, while refinery industry provided $38 \%$ of its export revenue. The export revenue of this industry more than quadrupled in 10 years. The refinery industry provided $2 \%$ of the country's GDP and more than 40 thousand jobs. But the crude oil is almost $100 \%$ imported one. Another problem was decreasing demand in 2008-13 for petroleum products both in Greece and abroad, but the refining industry became increasingly export-oriented one. 
Table 1

Energy vulnerability of the EU-15 in 2005

\begin{tabular}{|l|c|c|c|c|}
\hline \multicolumn{1}{|c|}{ Country } & $\begin{array}{c}\text { Oil import } \\
\text { vulnerability } \\
\text { indicator }\end{array}$ & $\begin{array}{c}\text { Natural gas } \\
\text { import vul- } \\
\text { nerability in- } \\
\text { dicator }\end{array}$ & $\begin{array}{c}\text { Oil combined } \\
\text { vulnerability } \\
\text { indicator }\end{array}$ & $\begin{array}{c}\text { Natural gas } \\
\text { combined } \\
\text { vulnerability } \\
\text { indicator }\end{array}$ \\
\hline Finland & 0.77 & 1.0 & 44.5 & 23.5 \\
\hline Sweden & 0.29 & 0.00 & 14.7 & 0.0 \\
\hline Greece & 0.29 & 0.72 & 15.3 & 6.0 \\
\hline Belgium & 0.28 & 0.15 & 20.1 & 7.2 \\
\hline Germany & 0.19 & 0.31 & 9.9 & 11.6 \\
\hline Netherlands & 0.16 & 0.00 & 9.9 & 0.0 \\
\hline Austria & 0.16 & 0.49 & 8.5 & 16.4 \\
\hline Italy & 0.15 & 0.26 & 6.6 & 12.2 \\
\hline Portugal & 0.11 & 0.53 & 7.7 & 10.2 \\
\hline Spain & 0.10 & 0.26 & 6.2 & 7.8 \\
\hline France & 0.08 & 0.15 & 4.0 & 3.6 \\
\hline United Kingdom & 0.002 & 0.002 & 0.1 & 0.1 \\
\hline Denmark & 0.00 & 0.00 & 0.0 & 0.0 \\
\hline Ireland & 0.00 & 0.00 & 0.0 & 0.0 \\
\hline EU-15 & 0.09 & 0.10 & 4.8 & 3.6 \\
\hline
\end{tabular}

Source: Christie E. (2007).

International Energy Agency (2014) stated that oil was a dominant energy source in Greece, although the oil demand in the country has dropped since 2007. The share of oil and natural gas in total primary energy supply were $45 \%$ and $14 \%$ in 2012. $80 \%$ of imported oil came from Russia, Saudi Arabia, Iraq and Libya. $60 \%$ of natural gas was imported from Russia and 31\% more from Algeria and Turkey. Domestic production of oil accounted for only $0.5 \%$ of oil consumption. Greece was a net exporter of refined products, with $45 \%$ of the exports coming to Turkey, Singapore, Lebanon and Libya. Domestic production of natural gas provided only $0.1 \%$ of its consumption in the country.

Mitroulia (2014) cited Prime Minister Antonis Samaras who had stated that if indications hydrocarbon deposits had been proved it could generate public revenue of about $€ 150 \mathrm{bn}$ in 30 years. There were also mixed opinions of experts about potential progress in this area.

Several multinational companies are interested in Greek hydrocarbon potential deposits. Robin Dunnigan, the US Deputy State Secretary for Energy, 
mentioned the key role of Greece in energy planning of South East Europe and the Mediterranean Basin (Kanapakis (2017)).

As for now the daily production oil production in Greece increased to 2.3 million barrels in May 2017 (Knoema,(2017)) contrary to the forecasted decrease to 0.9 million barrels by International Energy Agency (2014), but it is still very far from energy self-sufficiency.

The effects of trade in oil and gas are analysed in several research papers.

As for effects on balance of payments, Kilian et al. (2007) suggested that oil price increase worsens trade deficit of a typical oil-importing country but the effect depends on the reasons of the price shock. Demand-driven oil price increase shock affects with a delay, while supply-driven price increase shocks worsen the trade deficit immediately. But non-oil trade balance improves which partially offsets the growing oil trade deficit. Possession of oil assets by oilimporting countries (as in case of the U.S.) can smooth the effect of oil price shocks for them.

There are also country-specific studies. In case of Turkey Korab (2011) has found no significant effect of oil prices on trade balance in Turkey. But a number of studies provide the opposite results. Açikalin and Uğurlu (2014) concluded that oil price affected trade balance of Turkey negatively but weakly in the short run. The negative effect is declining during 10 months period. Bayar and Karamelikli (2015) proved the effect of oil and natural gas prices on foreign trade balance of Turkey. Başarır and Erçakar (2016) discovered mutual granger causality of between crude oil prices and current account deficit in the short run.

In Azerbaijan the share of crude oil in exports was $60-80 \%$ (Hajiyev and Almas (2013)).

As for effects on employment, we can mention Agerton et al. (2015), although they analyse the case of oil and gas extraction in the U.S. They conclude that an additional rig-count creates 37 jobs immediately and 224 jobs in the long run. Also a $10 \%$ increase in rig-counts increases employment in this industry by $5 \%$. When they consider per capita indicators, an additional rig-count per million people raises total employment by $0.068 \%$. But they do not provide evidence of statistically significant impact on employment in manufacturing.

Brown (2015) concludes that an additional rig created 20 jobs within the same month, 62 jobs after 6 months and 100 jobs in the long run in the U.S oil and gas sector in 2010-2014. But employment response was lower than in 1980s because of growing capital intensiveness.

Hajiyev and Almas (2013) noted that in Azerbaijan oil industry provided $42 \%$ of its GDP. But only $0.9 \%$ employees worked in the oil sector. 
GDP and inflation. Hamilton (2000) stated that oil price increases affect GDP more than oil price decreases. But oil price increases after oil price decreases provide little use for forecasting GDP growth.

Raduzzi and Ribba (2017) proved the effects of oil price shocks on the GDP and consumer prices in several EU countries (Austria, Belgium, Finland, Greece, Ireland, Italy, the Netherlands, Portugal and Spain). The effect on inflation is fast, while the effect on the GDP is more delayed. A $10 \%$ oil price increase results in additional inflation which varies from 0.17 in Austria to 0.64 in Greece, and GDP reduction between 0.14 percentage points in Austria and 1.63 in Greece. Thus, Greece turned out to be the most sensitive to oil price shocks among the euro area countries in the sample.

Almas and Hajiyev (2014) concluded that actual economic growth in Azerbaijan was much faster that the dynamic equilibrium level of $9.5 \%$ annually in 1996-2010. The reason was growing oil production and oil revenue. But oil extraction peaked in 2010. Negative growth in that industry afterwards led to slowdown in industry and in the entire national economy (Aliyeva and Hajiyev (2016)).

But Yildiz and Ulusoy (2015) has found out that oil prices do not influence inflation in Turkey. The assumed explanation is that Turkey used inflation targeting monetary policy.

Transportation of hydrocarbons. Papanikolaou (2015) mentioned several pipelines to be constructed in Greece and neighbouring countries. Trans-Adriatic Pipeline (TAP) will enable transportation of $10-20 \mathrm{bcm}$ of gas annually. It envisages $\$ 1.5$ billion of foreign direct investment and creates 2000 direct jobs and 10000 collateral jobs. There is an option of reverse transportation in case of emergency and the pipeline will be interconnected with other pipelines to ensure security of energy supply for Europe. Another project is the Interconnector Greece-Bulgaria (IGB) with a total cost amounts to $250 \mathrm{mln}$ euros (it will allow two-way transportation of gas from Greece to Hungary and Ukraine (Memorandum of Understanding on the interconnection of Balkan gas pipelines (2017)). Ionian-Adriatic Pipeline (IAP) will connect TAP with Montenegro, Bosnia and Herzegovina, and Croatia.

Trans Adriatic Pipeline is currently under construction. It will facilitate transportation of gas from the Caspian region (in particular Shah Deniz field in Azerbaijan) to Italy through Greece and Albania. TAP will be connected with the Trans Anatolian Pipeline (TANAP) at the Greek-Turkish border. TAP will provide competitive operation costs. It is technically feasible and safe project (TAP Trans Adriatic Pipeline, 2017). Its shareholders are SOCAR, Snam, BP, Fluxys, Enagás and Axpo, and the project does not depend on public subsidies (Trans Adriatic Pipeline (2017a)). Moreover TAP provides social and environmental investment in local communities involved (Trans Adriatic Pipeline (2017b)). Besides transit TAP is expected to provide Greece with $1 \mathrm{bcm}$ of gas annually and creates jobs 
in Greek engineering and construction firms (Hellenic Ministry of Foreign Affairs (2017)).

Danchev S., Paratsiokas N. and Tsakanikas A. (2013) estimated that operation of Trans Adriatic Pipline will generate $€ 33-36$ billion of output in Greece, $€ 17-18$ billion of value added, 4300-4800 jobs during operation stage and 800010000 during construction phase. The project will especially be beneficial for Northern Greece region. Enlarged consumption of imported gas can cut costs for business in Greece and make its exporters more competitive, primarily in iron and steel industry, manufacturing of paper, pulp and print, and chemical and petrochemical industry.

Sartori et al. (2016) and Baconi (2017) consider prospects for extraction of gas in the East Mediterranean region (Cyprus, Israel and Egypt). One of the options to export the gas is construction of East Med gas pipeline. European Commission currently assesses economic feasibility of this project, while Greece, Cyprus, Israel and Italy expressed political support for the pipeline and decided to start preparations for the construction. They hope to complete it by 2025. Possible barriers include difficult terrain and claims of Turkey to sovereignty over Cypriot maritime space. The pipeline will transport gas through Crete and Greek mainland and will have a capacity of $8 \mathrm{bcm}$ (Hellenic Ministry of Foreign Affairs (2017)).

All these pipelines can turn Greece into an energy transit hub in the Southeast Europe region.

\section{Effect on balance of payments}

The EU and BSEC countries have various dependence on oil and gas imports and vulnerability in terms of trade deficit. We use data on export and import of petroleum, petroleum products and related materials, and gas, natural and manufacture (see table 2).

The largest share of oil and gas imports in total imports of goods is in Malta, Greece, Lithuania, Ukraine, Cyprus and Georgia. As for trade balance in this products relatively the GDP, only Azerbaijan and Russia have surplus, while the largest deficit is in Malta, Georgia, Ukraine and Armenia. The indicator in Greece is close to the EU average. We also consider the contribution of trade deficit in oil and gas to the current account deficit. The largest contribution is in Poland, although its current account deficit is only marginal. It is followed by Lithuania, Greece and Ukraine. Therefore despite current account deficit in Greece is rather low nowadays, the necessity to increase domestic extraction of oil and gas is caused by high external debt and large contribution of oil and gas imports to the remaining current account deficit. 
Table 2

Vulnerability of countries to oil and gas imports in 2016

\begin{tabular}{|c|c|c|c|c|}
\hline Country & $\begin{array}{l}\text { Imports of pe- } \\
\text { troleum, pe- } \\
\text { troleum prod- } \\
\text { ucts and gas, } \\
\% \text { of imports } \\
\text { of goods }\end{array}$ & $\begin{array}{l}\text { Trade bal- } \\
\text { ance in petro- } \\
\text { leum, petro- } \\
\text { leum prod- } \\
\text { ucts and gas, } \\
\% \text { of GDP }\end{array}$ & $\begin{array}{c}\text { Current } \\
\text { account } \\
\text { balance, } \\
\% \text { of GDP }\end{array}$ & $\begin{array}{l}\text { Trade balance in } \\
\text { petroleum, petro- } \\
\text { leum products } \\
\text { and gas, \% of } \\
\text { current account } \\
\text { deficit (if relevant) }\end{array}$ \\
\hline Albania & 5.9 & -0.6 & -12.1 & 4.9 \\
\hline Armenia & 13.0 & -3.9 & -2.9 & 137.2 \\
\hline Austria & 5.3 & -1.7 & 2.4 & \\
\hline Azerbaijan & 1.0 & 25.1 & -3.8 & -663.4 \\
\hline Belgium & 9.8 & -2.1 & 1.0 & \\
\hline Bulgaria & 11.5 & -2.7 & 4.2 & \\
\hline Croatia & 8.8 & -2.1 & 3.9 & \\
\hline Cyprus & 17.8 & & -2.4 & \\
\hline $\begin{array}{l}\text { Czech } \\
\text { Republic }\end{array}$ & 3.7 & -2.0 & 1.1 & \\
\hline Denmark & 4.6 & -0.2 & 8.1 & \\
\hline Estonia & 8.8 & -2.2 & 2.7 & \\
\hline Finland & 10.1 & -0.7 & -1.1 & 70.2 \\
\hline France & 8.0 & -1.4 & -1.1 & 132.7 \\
\hline Georgia & 13.6 & -6.6 & -12.4 & 53.4 \\
\hline Germany & 6.6 & -1.5 & 8.5 & \\
\hline Greece & 21.7 & -1.4 & -0.6 & 225.8 \\
\hline Hungary & 5.0 & -2.7 & 4.3 & \\
\hline Ireland & 5.2 & -1.1 & 4.7 & \\
\hline Italy & 9.4 & -1.4 & 2.7 & \\
\hline Latvia & 8.4 & -2.9 & 1.5 & \\
\hline Lithuania & 15.9 & -2.6 & -0.9 & 287.3 \\
\hline Luxembourg & 5.9 & -2.1 & 4.8 & \\
\hline Malta & 32.6 & -8.6 & 5.8 & \\
\hline Netherlands & 12.4 & -1.0 & 9.6 & \\
\hline Poland & 5.6 & -1.7 & -0.3 & 557.4 \\
\hline Portugal & 9.5 & -1.6 & 0.8 & \\
\hline $\begin{array}{l}\text { Republic } \\
\text { of Moldova }\end{array}$ & 11.0 & & -3.4 & 0.0 \\
\hline Romania & 5.1 & -1.0 & -2.4 & 40.7 \\
\hline $\begin{array}{l}\text { Russian } \\
\text { Federation }\end{array}$ & 0.8 & 10.8 & 1.7 & \\
\hline Serbia & 7.5 & -3.2 & -4.0 & 79.3 \\
\hline
\end{tabular}




\begin{tabular}{|l|c|c|c|c|}
\hline \multicolumn{1}{|c|}{ Country } & $\begin{array}{c}\text { Imports of pe- } \\
\text { troleum, pe- } \\
\text { troleum prod- } \\
\text { ucts and gas, } \\
\text { \% of imports } \\
\text { of goods }\end{array}$ & $\begin{array}{c}\text { Trade bal- } \\
\text { ance in petro- } \\
\text { leum, petro- } \\
\text { leum prod- } \\
\text { ucts and gas, } \\
\text { \% of GDP }\end{array}$ & $\begin{array}{c}\text { Current } \\
\text { account } \\
\text { balance, } \\
\text { \% of GDP }\end{array}$ & $\begin{array}{c}\text { Trade balance in } \\
\text { petroleum, petro- } \\
\text { leum products } \\
\text { and gas, \% of } \\
\text { current account } \\
\text { deficit (if relevant) }\end{array}$ \\
\hline Slovakia & 5.8 & -2.0 & 0.4 & \\
\hline Slovenia & 6.3 & -2.5 & 6.8 & 18.2 \\
\hline Spain & 10.5 & -1.7 & 2.0 & 1.9 \\
\hline Sweden & 8.2 & -0.9 & 4.7 & \\
\hline Turkey & 4.5 & -0.7 & -3.8 & -3.6 \\
\hline Ukraine & 14.0 & -5.8 & -4.4 & \\
\hline $\begin{array}{l}\text { United } \\
\text { Kingdom }\end{array}$ & 5.9 & -0.5 & 2.2 & \\
\hline $\begin{array}{l}\text { European } \\
\text { Union }\end{array}$ & 8.0 & -1.3 & & \\
\hline
\end{tabular}

Source: authors' calculations and data of UNCTAD and IMF's World Economic Outlook Database.

We also calculated correlations between trade balance in petroleum, petroleum products and gas on one hand and current account balance on the other hand (see table 3). Both indicators are measured as \% of GDP.

Table 3

Correlations between trade balance in oil and gas industry and current account

\begin{tabular}{|l|c|c|c|}
\hline \multicolumn{1}{|c|}{ Country } & $1995-2016$ & $2002-2016$ & $2008-2016$ \\
\hline Albania & 0.26 & 0.12 & 0.60 \\
\hline Austria & -0.77 & -0.11 & 0.15 \\
\hline Azerbaijan & 0.89 & 0.85 & 0.97 \\
\hline Belgium & 0.79 & 0.63 & 0.49 \\
\hline Bulgaria & & 0.02 & 0.51 \\
\hline Croatia & -0.33 & -0.09 & 0.33 \\
\hline Czech Republic & 0.21 & 0.35 & 0.59 \\
\hline Denmark & -0.35 & -0.91 & -0.93 \\
\hline Estonia & 0.33 & 0.37 & 0.22 \\
\hline Finland & 0.47 & 0.35 & 0.15 \\
\hline
\end{tabular}


Oil and natural gas trade balance and production effects in the European Union and Black Sea Economic Cooperation countries

\begin{tabular}{|c|c|c|c|}
\hline Country & $1995-2016$ & $2002-2016$ & $2008-2016$ \\
\hline France & 0.75 & 0.65 & 0.40 \\
\hline Germany & -0.73 & -0.40 & 0.56 \\
\hline Greece & 0.49 & 0.29 & 0.34 \\
\hline Hungary & -0.61 & -0.52 & -0.27 \\
\hline Ireland & 0.43 & 0.35 & 0.57 \\
\hline Italy & 0.50 & 0.23 & 0.42 \\
\hline Latvia & & 0.10 & 0.45 \\
\hline Lithuania & -0.27 & -0.30 & 0.11 \\
\hline Luxembourg & 0.30 & -0.27 & -0.70 \\
\hline Malta & -0.63 & -0.67 & -0.90 \\
\hline Netherlands & -0.52 & -0.14 & 0.08 \\
\hline Poland & 0.40 & 0.63 & 0.72 \\
\hline Portugal & 0.17 & 0.18 & 0.30 \\
\hline Republic of Moldova & & & 0.76 \\
\hline Romania & & 0.63 & 0.60 \\
\hline Russian Federation & 0.62 & 0.43 & 0.42 \\
\hline Serbia & & & 0.87 \\
\hline Slovakia & 0.06 & -0.01 & 0.30 \\
\hline Slovenia & 0.05 & 0.22 & 0.54 \\
\hline Spain & 0.16 & -0.01 & 0.21 \\
\hline Sweden & -0.70 & -0.46 & -0.56 \\
\hline Turkey & -0.20 & -0.14 & 0.61 \\
\hline Ukraine & -0.02 & 0.17 & 0.30 \\
\hline United Kingdom & 0.73 & 0.65 & 0.19 \\
\hline
\end{tabular}

Source: authors' calculations (data of UNCTAD and IMF's World Economic Outlook Database).

In the previous 1-2 decades current account of several countries tend to be largely dependent on trade balance in petroleum, petroleum products and gas: Azerbaijan, Poland, Romania and partially in Belgium, France, Moldova, Serbia, Romania and United Kingdom. Stable negative correlation was in Denmark and Malta. In Greece the correlation was positive but not high.

In 2000-2011 trade balance in petroleum, petroleum products and gas in Greece accounted for about $30 \%$ of current account deficit. Since then the ratio increased several times because the current account balance radically improved (see Figure 1). 
Figure 1

The effect of trade balance in petroleum, petroleum products and gas on current account balance in Greece

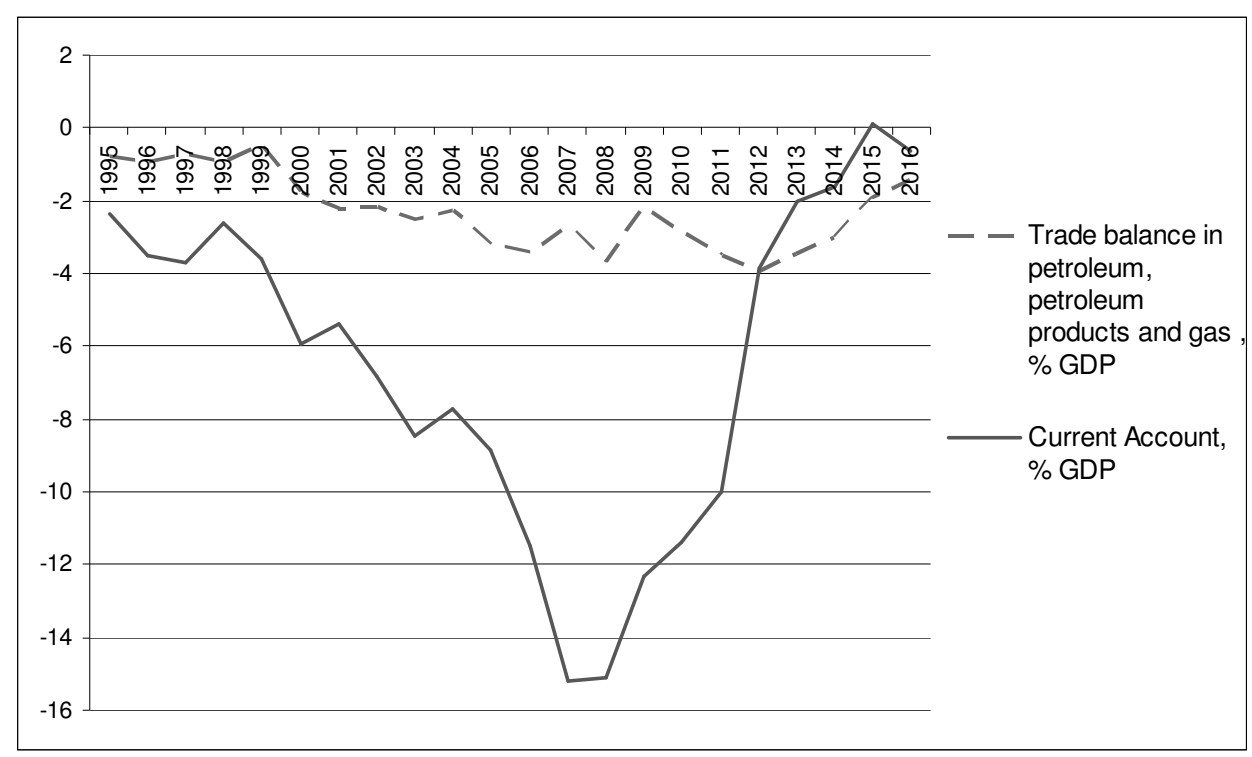

Source: authors' calculations (data of UNCTAD and IMF's World Economic Outlook Database).

Greece will need increase production of petroleum and gas (by $\$ 1.2$ billion more) in order to balance its current account. If it the trade balance in this sector is balanced (by increasing the production by $\$ 2,8$ billion) it will enable Greece to achieve current account surplus 0.8\% GDP. In 2016 Greece imported oil worth $€ 9.0$ billion (Bank of Greece (2017)). Full substitution of oil import can save part of the amount annually considering correction for imports of equipment for extraction. 


\section{Effect on creation of jobs}

We further perform a correlation and regression analysis to assess a possible impact of oil and gas extraction on labour market and refining industry. We use Eurostat data for value added in mining (and quarrying) as a proxy variable although this measure includes mining of other fossil fuels and non-fuel minerals. Therefore our conclusions for the impact of oil and gas industry will be preliminary and should be treated with caution. Also use of the Eurostat data enabled us to consider the EU member states only with one exception (Turkey).

First we consider correlation of value added in mining with employment in this sector. We use data for the number of employees with the age 15-64 years old (male and female). In the Table 4 we show the correlations for two periods: 1999-2007 and 2008-2015 (or 2008-2016 whenever the data is available).

\section{Table 4}

Correlation between number of employees and value added in mining and quarrying (in constant prices of 2010)

\begin{tabular}{|l|c|c|}
\hline \multicolumn{1}{|c|}{ Country } & $1999-2007$ & $2008-2015 / 16$ \\
\hline European Union & 0.65 & 0.63 \\
\hline Belgium & 0.79 & 0.27 \\
\hline Bulgaria & -0.77 & -0.47 \\
\hline Czech Republic & 0.48 & 0.73 \\
\hline Denmark & -0.33 & -0.77 \\
\hline Germany & 0.74 & 0.79 \\
\hline Estonia & -0.52 & -0.37 \\
\hline Ireland & 0.65 & -0.04 \\
\hline Greece & -0.40 & 0.67 \\
\hline Spain & -0.73 & 0.72 \\
\hline France & 0.63 & -0.80 \\
\hline Croatia & 0.16 & 0.73 \\
\hline Italy & 0.80 & 0.10 \\
\hline Cyprus & & -0.02 \\
\hline Latvia & & -0.14 \\
\hline Hungary & -0.30 & 0.80 \\
\hline Netherlands & -0.01 & -0.59 \\
\hline Austria & -0.47 & 0.41 \\
\hline Poland & 0.19 & -0.49 \\
\hline
\end{tabular}


Vol. 16. № 3 (62). July-September 2017

ISSN 2519-4070

\begin{tabular}{|l|c|c|}
\hline \multicolumn{1}{|c|}{ Country } & $1999-2007$ & $2008-2015 / 16$ \\
\hline Portugal & 0.31 & 0.62 \\
\hline Romania & -0.16 & 0.54 \\
\hline Slovenia & -0.01 & 0.50 \\
\hline Slovakia & 0.80 & 0.31 \\
\hline Finland & 0.15 & 0.78 \\
\hline Sweden & -0.32 & -0.61 \\
\hline United Kingdom & -0.47 & -0.58 \\
\hline Turkey & & -0.76 \\
\hline
\end{tabular}

Source: authors' calculations (data of Eurostat).

We see that the correlation for aggregate indicators of the EU is positive (0.63-65) and has not changed as a result of the crisis in 2008-09. But correlations in individual countries vary largely and sometimes changed as a result of the crisis. There are high positive significant or almost significant correlations in 2008-2015/16 in Hungary, Germany, Finland, Czech Republic, Croatia, Spain, Greece and Portugal. At the same time high negative correlation existed in France, Denmark, Turkey and Sweden. But only few countries experience stable correlations in both periods. In Greece the correlation in 1999-2007 was originally insignificantly negative and changed into positive in 2008-2015.

We also considered employment for specific groups of people in 20082015/16. The number of employees in mining (age 15-29) in the EU virtually did not correlate with the value added in the sector (although most countries did not report the data). In Greece correlation was insignificantly low as well (0.21). High positive correlation was registered only in Spain (0.82), Croatia (0.76) and Germany (0.64), while high negative one was in Poland $(-0.66)$.

As for employment (age 50 years and over), the correlation was negative in the EU (-0.69) and insignificantly positive in Greece (0.27). High positive correlation was registered only in Spain (0.90), Czech Republic (0.74), Hungary (0.65) and Croatia (0.64), while high negative one was in United Kingdom $(-0.79)$, the Netherlands $(-0.69)$ and Poland $(-0.64)$.

As for employment of females (age 15-64), the correlation was positive in the EU (0.67), but most countries did not report the data. High positive correlation was registered only in Croatia (0.98), while high negative one was in Bulgaria $(-0.67)$.

Employment of males (age 15-64) has similar correlations as employment of both males and females. Therefore we can be more sure that on average larger value added in mining leads to larger employment at least for males and middle age group of people, although even in this case the correlation largely 
depends on a country and period of time. As for Greece, the correlation seems to be almost significantly positive since 2008 , but mining is unlikely to increase employment of youth and elderly people.

In order to assess the impact we use data for Greece in 2002-2015 to perform a linear and nonlinear regression analysis. The linear regression is:

$$
E=-3.43+0.02 V A
$$

where $E$ - number of employees in mining and quarrying in Greece (age 15-64) in thousands, $V A$ - value added in mining and quarrying in million euro in constant prices of 2010. $R^{2}=0.46$ is significant at $p=0.008$. Thus each additional 50000 euro of value added in this sector creates 1 additional job in the industry. This is a direct impact on employment. But non-linear regression can provide more realistic relationship (see figure 2). Since the value added in Greece was 717 million euro in 2015 (prices of 2010), which is rather low number, the shortterm marginal effect on employment will be lower than the long-term effect under continuous growth in the mining industry.

\section{Figure 2}

The effect of value added in mining and quarrying in Greece on employment in the sector

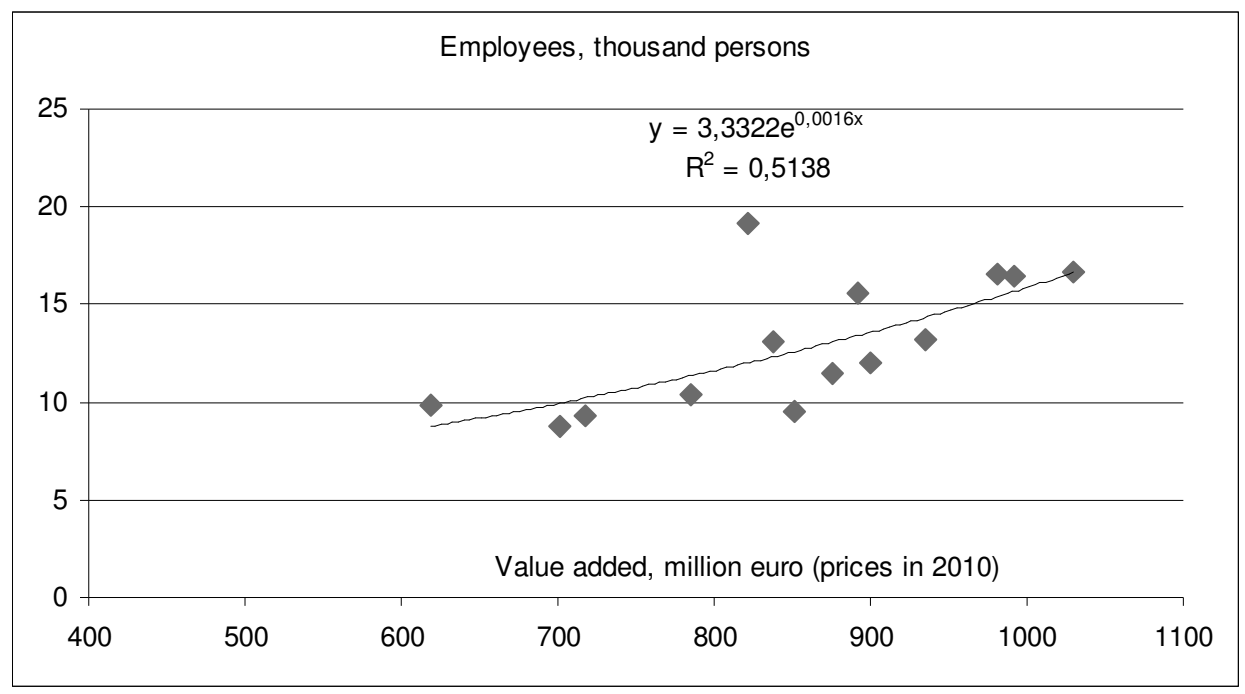

Source: authors' calculations (data of Eurostat). 
According to our calculation balancing current account of Greece can be achieved by creating approximately 23000 jobs in oil and gas industry, elimination of trade deficit in oil and gas means 53000 new jobs and consumptions of $100 \%$ domestic petroleum would create up to 180000 jobs. Together with employment because of construction and operation of new pipelines the optimistic estimate can be up to 200000 jobs. But the actual number will probably be smaller considering that:

- the actual amount of new deposits of hydrocarbons is not known;

- we used data for the entire mining industry in our model while oil and gas industry can be less labour intensive;

- business cycles significantly affect elasticity of employment;

- new technologies will probably make extraction less labour intensive especially in future.

Therefore several dozens of thousands of new jobs in the sector in the long run is a more realistic estimate, but the indirect effect of growing demand for other goods and services can probably provide another several dozens of thousands of new jobs in other industries.

\section{Effect on compensation of employees}

As for the effect on compensation of employees we use the Eurostat data both for the compensation and the value added in current prices (growth indicators in \%). The correlations have been calculated for 3 periods (see table 5). Unlike in case of correlation between static indicators correlation between growth indicators remain highly positive after 2008 both for the EU and Greece.

Table 5

Correlation between compensation of employees and value added in mining and quarrying

\begin{tabular}{|l|c|c|c|}
\hline \multicolumn{1}{|c|}{ Country } & $1996-2015 / 16$ & $2002-2015 / 16$ & $2008-2015 / 16$ \\
\hline European Union & & 0.58 & 0.64 \\
\hline Belgium & 0.84 & 0.86 & 0.97 \\
\hline Bulgaria & & -0.15 & -0.14 \\
\hline Czech Republic & 0.82 & 0.84 & 0.78 \\
\hline Denmark & 0.15 & 0.03 & 0.24 \\
\hline Germany & -0.17 & -0.37 & -0.47 \\
\hline
\end{tabular}


Oil and natural gas trade balance and production effects in the European Union and Black Sea Economic Cooperation countries

\begin{tabular}{|c|c|c|c|}
\hline Country & $1996-2015 / 16$ & $2002-2015 / 16$ & $2008-2015 / 16$ \\
\hline Estonia & 0.53 & 0.32 & -0.22 \\
\hline Ireland & 0.49 & 0.59 & 0.54 \\
\hline Greece & 0.60 & 0.54 & 0.55 \\
\hline Spain & 0.79 & 0.80 & 0.41 \\
\hline France & 0.33 & 0.41 & 0.61 \\
\hline Croatia & & -0.02 & 0.09 \\
\hline Italy & 0.37 & 0.22 & 0.00 \\
\hline Cyprus & 0.23 & 0.23 & -0.01 \\
\hline Latvia & 0.57 & 0.81 & 0.18 \\
\hline Lithuania & 0.63 & 0.46 & 0.42 \\
\hline Luxembourg & -0.25 & -0.26 & -0.52 \\
\hline Hungary & 0.56 & 0.31 & 0.37 \\
\hline Netherlands & -0.05 & -0.23 & 0.08 \\
\hline Austria & -0.15 & -0.18 & -0.03 \\
\hline Poland & & 0.55 & 0.65 \\
\hline Portugal & 0.20 & -0.08 & -0.47 \\
\hline Romania & 0.18 & 0.44 & -0.03 \\
\hline Slovenia & 0.53 & 0.41 & 0.55 \\
\hline Slovakia & 0.78 & 0.92 & 0.84 \\
\hline Finland & 0.41 & 0.43 & 0.04 \\
\hline Sweden & 0.70 & 0.71 & 0.75 \\
\hline United Kingdom & 0.52 & 0.61 & 0.56 \\
\hline Turkey & & & 0.82 \\
\hline
\end{tabular}

Source: authors' calculations (data of Eurostat).

The correlations for the EU and Greece prove intuitive assumption that growth of value added in the mining industry means growth of compensation of employees besides profit of companies. These correlations are especially high in Belgium, Czech Republic, Slovakia, Sweden and Turkey. There are also some exceptions when the correlation is insignificantly negative (Bulgaria, Germany, Luxemburg and Austria) where income to wages pass-through in the mining industry is questioned.

In order to assess the impact we use data for the EU in 2001-2015 to perform a linear regression analysis. The linear regression is:

$$
G C E=1.46+0.22 G V A
$$

where GCE - growth of compensation of employees in mining and quarrying in $\%$, GVA - growth value added in mining and quarrying in $\% . R^{2}=0.34$ is significant at $p=0.02$. The regression coefficient shows that elasticity is rather low, i. e. $1 \%$ growth of value added means $0.2 \%$ growth of compensation of employees. 
Figure 3

The effect of value added in mining and quarrying in the EU on compensation of employees in the sector

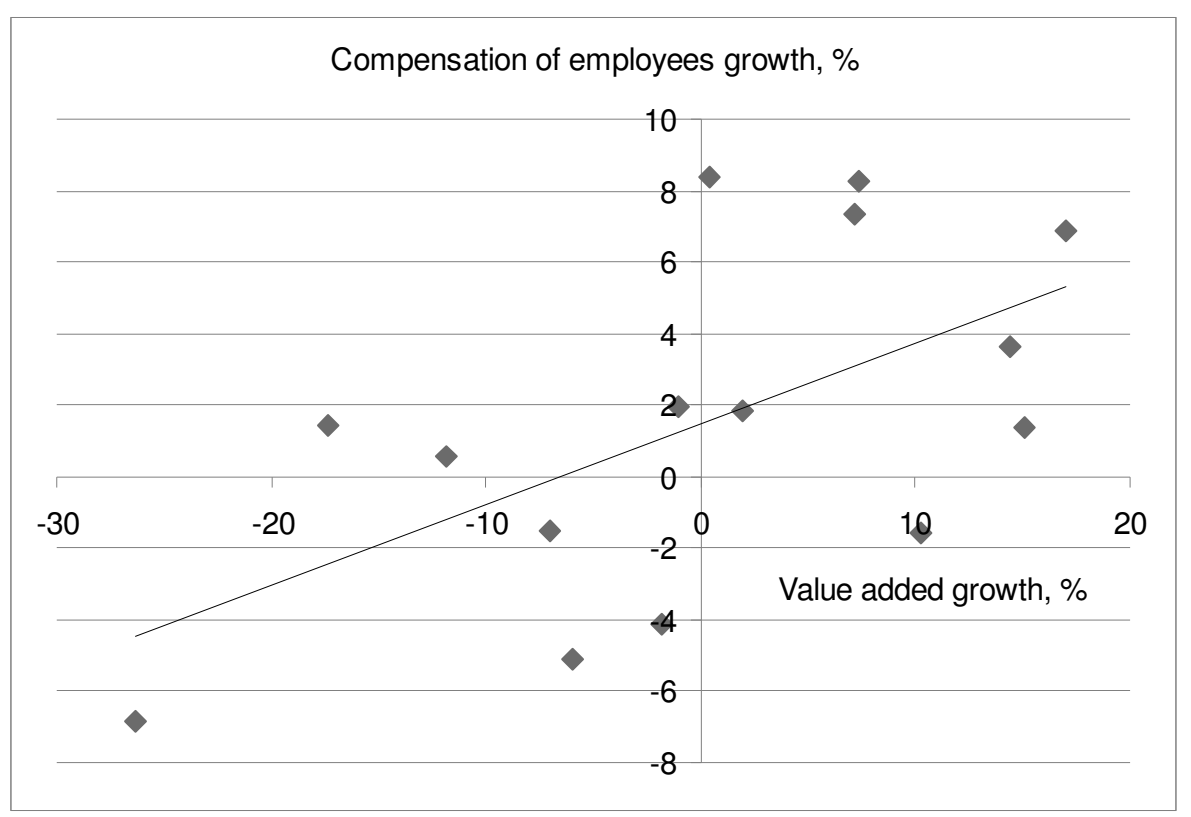

Source: authors' calculations (data of Eurostat).

A similar linear regression for mining and quarrying in Greece is:

$$
G C E=-1.32+0.55 G V A
$$

$R^{2}=0.29$ is significant at $p=0.04$. The elasticity in Greece is higher and is equal 0.55 . Enlargement of the period considered to 1996-2015 does not change the elasticity. This means that under an economic boom in the sector employees would benefit relatively more from it that in the EU on average, but under a crisis employees would experience deeper fall in income. 
Figure 3

The effect of value added in mining and quarrying in Greece on compensation of employees in the sector

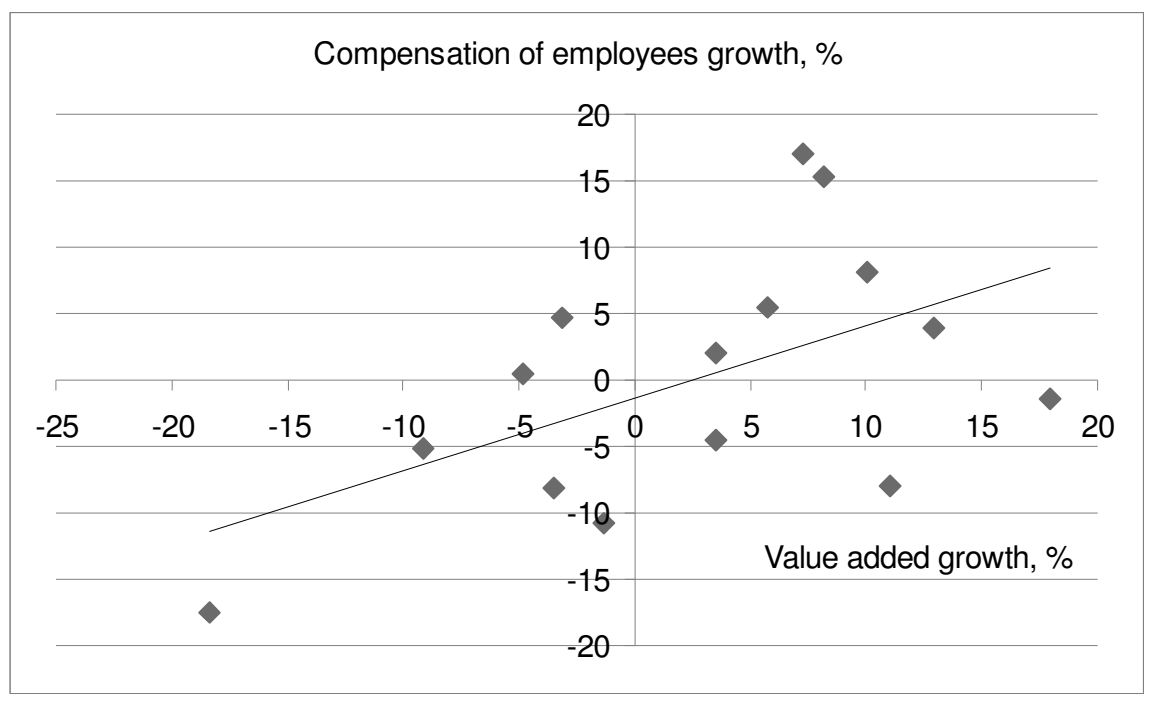

Source: authors' calculations (data of Eurostat).

\section{Effect on value added in refining industry}

In this case we use the Eurostat data for the value in current prices (growth indicators in \%) in mining and quarrying on one hand and manufacture of coke and refined petroleum products on the other hand. The correlations are shown in table 6.

High positive correlations like in Poland, the Netherlands, Spain, Turkey, Italy mean that national mining and refinery industries probably support development of each other, i.e. the cluster effect exists. High negative correlations like in Romania and recently in the United Kingdom evidence that these sectors mostly rely on foreign demand or supply or transfer pricing exists. As for Greece the correlation is insignificant and close to zero. In this case also development of both sectors is partially disentangled and foreign supply for refinery industry and demand for mining industry are important. Therefore we assume that development of oil and gas extraction industry in Greece will not lead to substantial benefits for refinery industry in the short run, although the long term effects have not been analysed in our paper. 
Table 6

Correlation between value added in mining and quarrying and manufacture of coke and refined petroleum products

\begin{tabular}{|l|c|c|c|}
\hline \multicolumn{1}{|c|}{ Country } & $1996-2014 / 15 / 16$ & $2002-2014 / 15 / 16$ & $2008-2014 / 15 / 16$ \\
\hline European Union & & 0.64 & 0.90 \\
\hline Belgium & -0.11 & -0.16 & -0.12 \\
\hline Bulgaria & & 0.29 & 0.27 \\
\hline Czech Republic & 0.31 & 0.35 & 0.47 \\
\hline Denmark & -0.15 & -0.21 & -0.52 \\
\hline Germany & -0.08 & -0.02 & -0.31 \\
\hline Estonia & -0.05 & -0.05 & -0.04 \\
\hline Greece & 0.14 & -0.17 & -0.14 \\
\hline Spain & 0.31 & 0.51 & 0.77 \\
\hline France & 0.29 & 0.14 & 0.16 \\
\hline Italy & 0.37 & 0.42 & 0.60 \\
\hline Cyprus & -0.48 & -0.52 & -0.43 \\
\hline Latvia & & 0.17 & 0.10 \\
\hline Hungary & 0.52 & 0.54 & 0.45 \\
\hline Netherlands & 0.60 & 0.69 & 0.78 \\
\hline Austria & -0.42 & -0.43 & -0.46 \\
\hline Poland & & 0.71 & 0.79 \\
\hline Portugal & 0.30 & 0.35 & 0.26 \\
\hline Romania & -0.45 & -0.58 & -0.78 \\
\hline Slovenia & 0.18 & -0.35 & 0.30 \\
\hline Slovakia & 0.02 & 0.00 & 0.07 \\
\hline Finland & 0.01 & 0.14 & 0.16 \\
\hline Sweden & -0.11 & -0.30 & -0.61 \\
\hline United Kingdom & -0.27 & -0.24 & -0.65 \\
\hline Turkey & & & 0.67 \\
\hline
\end{tabular}

Source: authors' calculations (data of Eurostat).

\section{Conclusion}

Net importers of oil and natural gas in European and Black Sea region can improve their energy security by searching for new deposits. Nowadays Greece is largely vulnerable to oil import dependency due to its refinery industry demand. Subject to discovery of new deposits Greece will need to increase production of petroleum and natural gas by $\$ 1.2$ billion in order to balance its current account. 
Another energy security action is construction of new gas pipelines: TransAdriatic Pipeline, Interconnector Greece-Bulgaria, Ionian-Adriatic Pipeline and possibly East Med pipeline.

Import dependency of GDP on oil and natural gas is much larger in Malta, Georgia, Ukraine, Serbia and Latvia, although correlation analysis provides different results for dependency of current account of hydrocarbons trade balance. On the other hand Russia and Azerbaijan are large net exporters of hydrocarbons.

Preliminary conclusions about the link between extraction and employment is that correlation largely vary across countries and time periods. On average larger value added in mining leads to larger employment at least for males and middle age group of people. We have estimated the direct effect on employment in Greece. Approximately each additional 50000 euro of value added in this sector can create 1 additional job in the industry. Together with construction of new pipelines growth of extraction can result in dozens of thousands of new jobs in Greece.

There is a closer link between value added in mining and compensation of employees in that industry. $1 \%$ growth of value added means $0.2 \%$ growth of compensation of employees in the EU and $0.55 \%$ in Greece.

We have found evidence that the clustering effect between mining and manufacture of refined petroleum products and coke exists only in some EU countries, and there is no such effect now in Greece considering that it imports almost $100 \%$ of crude oil it uses. The effect can appear only if Greece considerably substitutes crude oil imports with domestic extraction.

\section{References}

1. Açikalin, S., Uğurlu, E. (2014). Oil Price Fluctuations and Trade Balance of Turkey. Procedia of Economics and Business Administration, vol. 1 (1), pp. 6-13.

2. Agerton, M., Hartley, P., Medlock, III K. B., Temzelides, T. (2015). Employment Impacts of Upstream Oil and Gas Investment in the United States. IMF Working Paper WP/15/28.

3. Aliyeva, G. T., Hajiyev, N. (2016). New Approaches to the State Industry Competition Policy. Journal of Global Economy Review, No 6, pp. 42-53.

4. Almas, L., Hajiyev, N. (July 16-18, 2014). Estimating Dynamic Equilibrium Level of Economic Growth for the Period of Oil Revenues and Competitive 
Environment. Paper prepared for presentation at the International Conference on Economic and Policy Modelling (EcoMod 2014), Bali, Indonesia.

5. Ausick, P. (2015). Greek Economy Relies on Refined Product Exports, 24/7 Wall St., 29 June Retrieved from: http://247wallst.com/energy-economy/ 2015/06/29/greek-economy-relies-on-refined-product-exports/

6. Baconi, T. (April 21, 2017). Pipelines and Pipedreams: How the EU Can Support a Regional Gas Hub in the Eastern Mediterranean. Retrieved from: http://www.ecfr.eu/publications/summary/pipelines_and_pipedreams_how_th e_eu_can_support_a_regional_gas_hub_in_7276.

7. Bank of Greece. (August 16, 2017). Balance of Goods. Retrieved from: http://www.bankofgreece.gr/Pages/en/Statistics/externalsector/balance/com mercial.aspx.

8. Başarır, C., Erçakar, M. E. (2016). An Analysis of the Relationship between Crude Oil Prices, Current Account Deficit and Exchange Rates: Turkish Experiment. International Journal of Economics and Finance, vol. 8 (11), pp. 48-59.

9. Bayar, Y., Karamelikli, H. (2015). Impact of Oil and Natural Gas Prices on the Turkish Foreign Trade Balance: Unit Root and Cointegration Tests with Structural Breaks. Romanian Economic and Business Review 10(3), pp. 91103.

10. Brown, J. P. (2015). The Response of Employment to Changes in Oil and Gas Exploration and Drilling. Federal Reserve Bank of Kansas City, Economic Review 100(2), pp. 57-81.

11. Costel, S. (2011). Future Developments on Oil and Gas Transport in the Black Sea region. Constanta Maritime University Annals, vol. 15(1), pp. 107110.

12. Christie, E. (2007). Oil and Gas Dependence of EU-15 Countries. The Vienna Institute for International Economic Studies. Research Report 343.

13. Danchev, S., Paratsiokas, N., Tsakanikas, A. (2013). Economic Impact from the Construction and Operation of the Trans Adriatic Pipeline on Greek Territory. Foundation for economic \& industrial research (IOBE). Athens, January 2013. TAP -Trans Adriatic Pipeline Retrieved from: http://www.idis.gr/ wpcontent/uploads/Economic-Impact-of-TAP_Final-report.pdf

14. Eurostat, (July 19, 2007). Database. Retrieved from http://ec.europa.eu/ eurostat/data/database.

15. Hajiyev, N., Almas, L. K. (July 1-3, 2013). Azerbaijan's Current and Potential Comparative Advantage: An Exploratory Study. Paper prepared for presentation at the International Conference on Policy Modelling (EcoMod 2013), Prague, Czech Republic, 2013. 
16. Hamilton, J. D. (2000). What is an Oil Shock? National Bureau of Economic Research. Working paper 7755.

17. Hellenic Ministry of Foreign Affairs. (April, 2017). Energy Diplomacy. Retrieved from: http://www.mfa.gr/en/energy-diplomacy/

18. International Energy Agency. (2014). Energy Supply Security 2014, Washington DC: IEA. Retrieved from: https://www.iea.org/media/ freepublications/security/EnergySupplySecurity2014_Greece.pdf.

19. International Monetary Fund. (July 19, 2017). World Economic Outlook Database, April 2017. Retrieved from http://www.imf.org/external/pubs/ $\mathrm{ft} /$ weo/2017/01/weodata/index.aspx.

20. Kanapakis, Y. (May 16, 2017). Energy Giants Set up Bases in Greece Hydrocarbons. Retrieved from: http://www.naftemporiki.gr/finance/story/ 1267299/energeiakoi-kolossoi-stinoun-baseis-stin-ellada.

21. Kilian, L., Rebucci, A., Spatafora, N. (2007). Oil Shocks and External Balances. IMF Working Paper WP/07/110.

22. Knoema, (August 08, 2017). Greece - Oil - Production of crude oil including lease condensate. Retrieved from https://knoema.com/atlas/Greece/topics/ Energy/Oil/Production-of-crude-oil

23. Korap, L. (3. August, 2011). An Empirical Model for the Turkish Trade Balance: New Evidence from ARDL Bounds Testing Analyses. MPRA Paper No. 32550. Retrieved from: http://mpra.ub.uni-muenchen.de/32550/

24. Lantz, F., Saint-Antonin, V., Gruson, J.-F., Suwala, W. (2012). The OURSE model: Simulating the World Refining Sector to 2030. European Commission, Joint Research Centre, Institute for Prospective Technological Studies.

25. Memorandum of Understanding on the Interconnection of Balkan Gas Pipelines (17.08.2017). Retrieved from: http://energyin.gr/2017/07/20/\% CE\%BC\%CE\%BD\%CE\%B7\%CE\%BC\%CF\%8C\%CE\%BD\%CE\%B9\%CE\% BF-\%CF\%83\%CF\%85\%CE\%BD\%CE\%B5\%CF\%81\%CE\%B3\%CE\%B1\% CF\%83\%CE\%AF\%CE\%B1\%CF\%82-\%CE\%B3\%CE\%B9\%CE\%B1-\%CF \%84\%CE\%B7-\%CE\%B4\%CE\%B9\%CE\%B1\%CF\%83\%CF\%8D\%CE\%BD\% CE\%B4\%CE\%B5/

26. Mitroulia, P. (May 12, 2014). Gas and Oil Reserves in Greece: Myths and Reality. Retrived from: https://www.energyworldmag.com/12/05/2014/gasand-oil-reserves-in-greece-myths-and-reality/

27. Papanikolaou, G. (November 9, 2015). «Southern Energy Corridor Conference» The Greek perspective. Paper presented at the conference «The Southern Gas Corridor in European Energy», 2015, University of Houston. 
28. Raduzzi, R., Ribba, A. (2017). The Macroeconomics Outcome of Oil Shocks in the Small Eurozone Economies. Universit a di Modena e Reggio Emilia, DEMB Working Paper Series 109.

29. Sartori, N., Colantoni, L., Paceviciute, I. (2016). Energy Resources and Regional Cooperation in the East Mediterranean. Rome, Istituto Affari Internazionali working paper 16/27.

30. Trans Adriatic Pipeline. (August 25, 2017a). TAP at a Glance. Retrieved from https://www.tap-ag.com/the-pipeline

31. Trans Adriatic Pipeline. (July 06, 2017b). TAP's progress in Greece: Works Begin in Western Macedonia \& Compressor Station. Retrieved from: https://www.tap-ag.com/news-and-events/2017/07/06/taps-progress-ingreece-works-begin-in-western-macedonia-andamp-compressor-station.

32. UNCTAD. (July 19, 2017). Data Centre. Retrieved from http://unctadstat.unctad.org/ wds/ReportFolders/reportFolders.aspx?sCS_ChosenLang=en.

33. Yildiz, E., Ulusoy, M. K. (2015). The Fragility of Turkish Economy from the Perspective of Oil Dependency Managing Global Transitions 13 (3), pp. 253266. 